\title{
Field Damage to Yellow Starthistle Infected by Synchytrium solstitiale, and Greenhouse Maintenance and Host Range of the Fungus
}

F. M. Eskandari, Biologist, W. L. Bruckart, III, Research Plant Pathologist, and T. L. Widmer, Research Plant Pathologist, USDA, ARS, Foreign Disease-Weed Science Research Unit, 1301 Ditto Ave., Ft. Detrick, MD 21702

\begin{abstract}
Eskandari, F. M., Bruckart, W. L., III, and Widmer, T. L. 2011. Field damage to yellow starthistle infected by Synchytrium solstitiale, and greenhouse maintenance and host range of the fungus. Plant Dis. 95:907-912.

Yellow starthistle (YST, Centaurea solstitialis) is a major weed pest of the western United States. Synchytrium solstitiale, a pathogen of YST, caused significant damage to symptomatic (versus asymptomatic) plants in a field study in France. Before it was evaluated as a candidate for biological control of YST in the United States, protocols for pathogen maintenance under greenhouse conditions were developed. Maintenance, increase, and host range determination protocols involved incubation at $10 / 15^{\circ} \mathrm{C}$ (night/day) with an 8 -h photoperiod

flasks of water) plants inoculated with galled leaf tissue, or potted plants in which inoculum was wrapped within healthy leaves by a plastic wrap. The leaf-wrap protocol, used during the host range determination, always resulted in disease of YST. Several safflower (Carthamus tinctorius) cultivars and other plants related to YST became diseased following this protocol, thus raising concern about host specificity. Development of disease on nontarget species precludes proposal of $S$. solstitiale for biological control of YST at this time.
\end{abstract} either of potted or exhumed (i.e., roots of 4-week-old plants grown in
Yellow starthistle (YST, Centaurea solstitialis L.) is an important weed in the United States that remains a pest despite release of seven insect agents (11) and a plant pathogen $(4,10)$ for biological control. Additional agents are desired, because YST densities have not been reduced to manageable levels to date, and there is concern that the species continues to increase and spread (6). One promising candidate in the Chytridiales is Synchytrium solstitiale Widmer (7), the cause of false rust disease on YST in France (Fig. 1A). Plants in France were severely diseased by $S$. solstitiale from November through February (9). In California, YST is not under pressure from the currently available biological control agents during that time of the year; thus the timing of disease development in France makes $S$. solstitiale very appealing as a candidate for biological control.

Although appealing for biological control, a limited host range determination conducted in France indicated six other species in the Asteraceae, Tribe Cardueae, were potential hosts of S. solstitiale (9). YST from the United States (California) was also very susceptible in those tests; $95 \%$ of the seedlings developed sporangial galls. Most notable among nontarget species found susceptible in that study were seedlings of commercially important safflower (Carthamus tinctorius L.) and two North American natives, Plectocephalus americanus (Nutt.) D. Don (=Centaurea americana Nutt.) and Plectocephalus rothrockii (Greenm.) D.J.N. Hind (=C. rothrockii Greenm.), sustaining 10,10, and 25\% disease incidence, respectively, as well as Helianthus annuus L. (Asteraceae, Tribe Heliantheae), a species somewhat distantly related to YST that sustained $7 \%$ disease incidence. Seven other species were not infected in that study (9).

The French isolate of $S$. solstitiale was sent to the USDA, ARS, Foreign Disease-Weed Science Research Unit (FDWSRU) BSL-3

Corresponding author: W. L. Bruckart,

E-mail: william.bruckart@ars.usda.gov

Accepted for publication 28 March 2011.

doi:10.1094/PDIS-02-11-0139

This article is in the public domain and not copyrightable. It may be freely reprinted with customary crediting of the source. The American Phytopathological Society, 2011. containment greenhouse facility (5) for further evaluation as a candidate for biological control (Permit number P526P-07-04482; currently number P526P-09-02111). The extent of damage observed on YST in France justified the field evaluation of $S$. solstitiale, but disease on nontarget plants was of major concern and warranted further scrutiny (1). The truly obligate nature of this pathogen and the remote source of inoculum from the field necessitated development of maintenance protocols to study this pathogen under greenhouse conditions. The objectives of this research were to: (i) conduct additional field and laboratory studies on damage caused by $S$. solstitiale, (ii) describe protocols for greenhouse maintenance of the fungus, and (iii) provide results from additional host range investigations. Preliminary reports of results have been made $(2,3,8)$.

\section{Materials and Methods}

Field damage by $\boldsymbol{S}$. solstitiale. In each of two seasons in Cazevieille, France $\left(43^{\circ} 43^{\prime} 20^{\prime \prime} \mathrm{N}\right.$; $\left.03^{\circ} 47^{\prime} 42^{\prime \prime} \mathrm{E}\right), 10$ asymptomatic and 10 symptomatic YST plants were tagged at the rosette stage in late December. The following July, tagged plants were located and measured for height, plant area, and stem diameter $1 \mathrm{~cm}$ above the soil line. Capitula on each plant were also counted. The area occupied by the plant was calculated by measuring the plant diameter in two perpendicular directions intersecting at the center of the plant.

Inoculation protocols and tests for efficacy. The fungus was established upon receipt of infected material at the FDWSRU following a modified protocol used by Widmer and Guermache (9). Leaf pieces $\left(1 \mathrm{~cm}^{2}\right)$ containing orange sporangial galls were put at the center of 4- to 6-week-old YST rosettes in pots. Each inoculated plant was misted and set into a plastic bag that was closed with a twist-tie. Plants were incubated for 10 days at $10 / 15^{\circ} \mathrm{C}$ (night/day) with an 8-h photoperiod in a Percival growth chamber (Percival Scientific, Inc.) and misted daily during the incubation period by opening the top of each bag and applying water from an atomizer. Plastic bags were removed after 10 days, and plants were placed in a cool greenhouse maintained at $20( \pm 5)^{\circ} \mathrm{C}$ with natural light supplemented with 1,000-W halogen lamps to give a 14-h photoperiod. Plants were checked daily for symptom development. Fresh orange sporangial galls were then transferred to new rosettes, and the cycle was repeated. Four separate inoculations were made ( $n=8,12,14$, and 14 plants per inoculation), and data were recorded for the number of days until signs of the pathogen (both 
sporangial and resting spore galls) were visible. This is referred to as the "original protocol" throughout this paper.

A modification of the original protocol involved 4-week-old plants that had been exhumed from soil. Soil was washed carefully from roots, and plants were placed into flasks of sterile tap water. A piece of galled leaf tissue was placed at the center of the crown, and both galled leaf piece and plant were pushed down into the flask until the water covered the plant crown, leaf petioles, and small leaves at the center of rosettes. Plants were bagged, as described, and misted once only before the start of incubation. After incubation, plastic bags were removed and plants were lifted so that the apex was above the water while roots remained submerged (Fig. 2A).

Another modification for inoculations involved placing an infected leaf piece at the center of potted plants and binding misted, healthy leaves together using either a moist paper towel or plastic wrap (Plastic Wrap Clear, Giant Eagle, Inc.) (Fig. 2B). Misting was not used during the incubation period with this protocol, and plants were incubated as described for the original inoculation protocol.

Comparisons were made of inoculation protocols and incubation conditions. One experiment was a $2 \times 2$ factorial of incubation

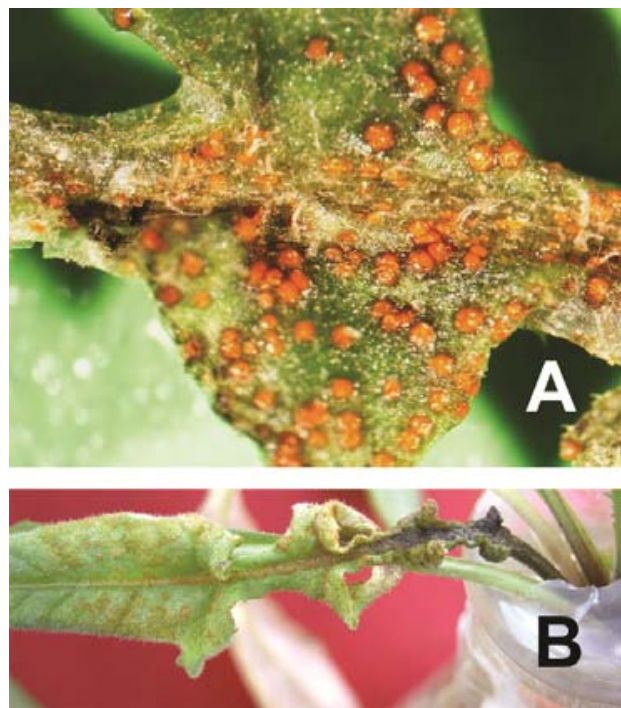

Fig. 1. Symptoms and signs of false rust disease, caused by Synchytrium solstitiale. A, False rust disease on yellow starthistle collected in France showing orange sporangial galls. B, Orange sporangial and resting spore galls (on leaf blade and petiole, respectively) after laboratory inoculation of an exhumed plant. venue (growth chamber versus dew chamber) and growth medium. For the latter, plants were inoculated following either the original protocol (grown in soil) or after they were exhumed (grown in water). Each incubation venue involved the same number of potted or exhumed plants $(n=32)$. Plants in the growth chamber treatment, whether potted or exhumed, were put into plastic bags and misted as described for each protocol. Plants in the dew chamber treatment, whether potted or exhumed, were not misted; free moisture inside the dew chamber developed from a natural dewfall process. Growth chamber conditions were as described previously, and dew chamber conditions included continuous lighting from a single $40-\mathrm{W}$ incandescent bulb and a constant $13^{\circ} \mathrm{C}$ temperature. All treatment combinations were included, and the experiment was run twice.

Comparison was made also between the leaf-wrap inoculation protocol and inoculation of exhumed plants. Two binding materials were tested for usefulness in maintaining free moisture on inoculated leaves, i.e., moist paper towel and plastic wrap, either alone or in combination. For comparisons, two additional treatments were exhumed, inoculated plants in sterile tap water and noninoculated control plants in pots. Plants were incubated as described in the growth chamber for 3 days and then set in a cool greenhouse. All wrapping was removed where appropriate and plants were monitored for disease. The experiment was run twice.

Incubation time. Shorter incubation times were compared to the standard incubation period of 10 days used in the original protocol. Following the inoculation protocol with exhumed plants in the growth chamber, plants were removed from the chamber 1, 2 , or 3 days after incubation, or they were kept in the growth chamber for the remainder of the standard 10-day incubation period. Plants were monitored for disease, and the date orange sporangial galls appeared was recorded for each plant. Rates of symptom development in these treatments were compared. This experiment was run twice.

Host range studies. The plastic leaf-wrap protocol was used for inoculation of plants in the host range determination. Focus of these tests was susceptibility of safflower cultivars and related plants in the Asteraceae, Tribe Cardueae, i.e., particularly species of Carthamus, Centaurea, Cirsium, and Cynara. Safflower cultivars tested during the course of study were 'CW 99 OL', 'S-345', and 'Finch'. Two additional Middle Eastern Carthamus species, $C$. glaucus M. Bieb. from Lebanon (PI \#243151) and C. palaestinus Eig from Israel (PI \#235663), were also tested. Helianthus annuus 'Mammoth' (Burpee \#6074A) was included, since it had been reported to be symptomatic by Widmer and Guermache (9). Data were recorded for number of sporangial galls per plant, visual rat-
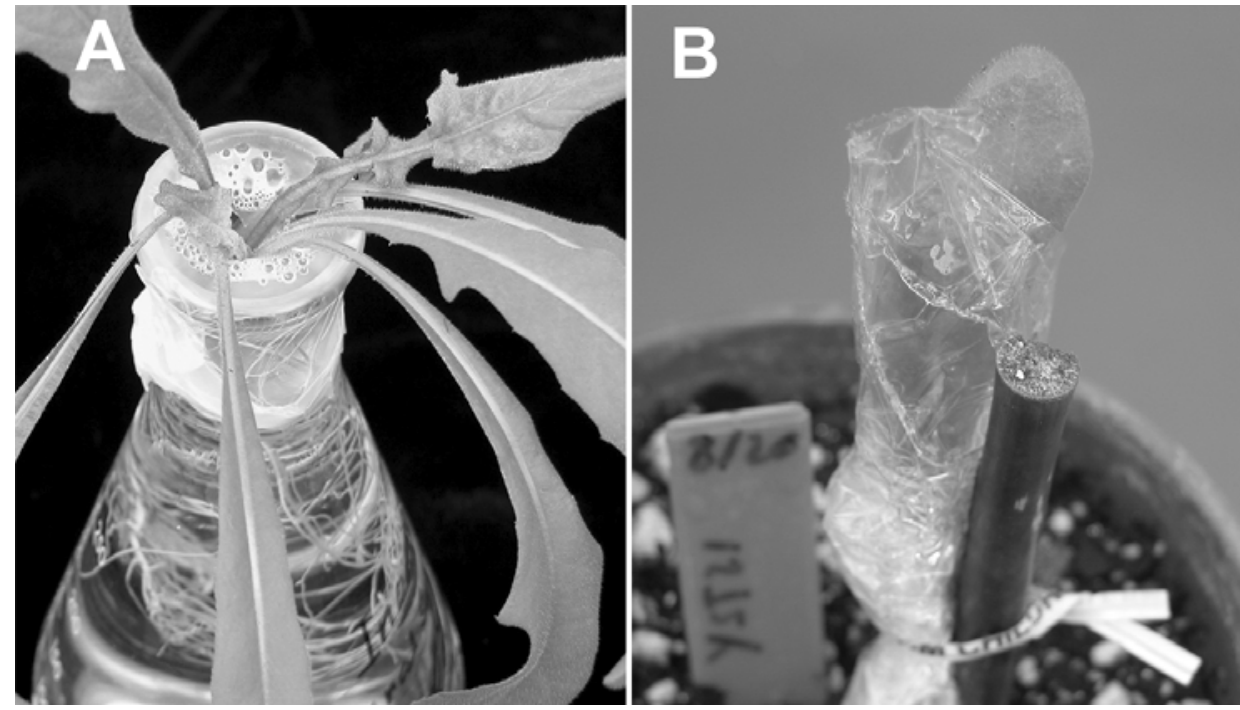

Fig. 2. Two protocols for inoculation of yellow starthistle (YST) with Synchytrium solstitiale. A, An exhumed plant growing in sterile tap water. B, Leaf-wrap-inoculated YST, the plastic wrap treatment illustrated. 
ings (in 10\% increments from 0 [=no macroscopic symptoms, $0 \%]$ to 10 [=severe disease, plant death, $100 \%$ ]), and calculation of both disease incidence and proportion of leaves infected.

Two additional inoculations of safflower using the leaf-wrap protocol were made to quantify effects of $S$. solstitiale on safflower growth and symptom development. The first involved four safflower cultivars at the 6-true-leaf stage, and the second involved two safflower cultivars at either the 2- or 4-true-leaf stage. Variables for analysis were plant height, shoot dry weight, average number of galls per plant, disease incidence, and proportion of infected leaves.

Data analysis. Data were analyzed using Proc GLM in SAS (SAS Institute; version 9.2). Least-squares means were generated along with probabilities of differences (PDIFF option). Differences between mean values were considered significant only if $P \leq 0.05$. Regression analysis (Proc Reg) was applied to data on incubation time.

\section{Results}

Naturally infected plants in France were severely damaged by $S$. solstitiale. Over a 2-year period, infected plants in the field were significantly smaller in comparison to controls $(P \leq 0.05)$. No macroscopic symptoms or signs developed on control plants, and infected plants sustained reductions of $58 \%$ in height, $81.7 \%$ in plant area, $20.0 \%$ in stem diameter, and $55.8 \%$ in capitula per plant (Table 1) compared to controls.

S. solstitiale has been maintained in the greenhouse since 2006 by following the original protocol for live propagation. Sporangial galls developed color about 2 weeks after inoculation (Fig. 1), and these sori could be used for new inoculations at that time. Sporan-

Table 1. Growth of yellow starthistle from a 2-year French field study of plants initially with or without symptoms of false rust disease caused by Synchytrium solstitiale

\begin{tabular}{|c|c|c|c|c|}
\hline \multirow[b]{2}{*}{ Variable } & \multicolumn{2}{|c|}{ Field symptoms ${ }^{t}$} & \multirow{2}{*}{$\begin{array}{c}\text { Probability } \\
\text { of difference }^{\mathrm{u}}\end{array}$} & \multirow{2}{*}{$\begin{array}{c}\% \\
\text { Difference }\end{array}$} \\
\hline & - & + & & \\
\hline Height $^{w}$ & 29.3 & 11.5 & $<0.01$ & 60.7 \\
\hline $\operatorname{Area}^{\mathrm{x}}$ & 321 & 48 & $<0.01$ & 85.0 \\
\hline Stem Diam. ${ }^{y}$ & 0.26 & 0.21 & 0.06 & 19.2 \\
\hline Capitula ${ }^{z}$ & 9.2 & 3.3 & $<0.01$ & 64.1 \\
\hline
\end{tabular}

${ }^{t}$ Plants were symptomatic (+) or not symptomatic (-) when tagged in the field.

u Probability that means for each variable are different.

v Percent average reduction compared to nonsymptomatic plants.

${ }^{\mathrm{w}}$ Least-squares mean values for height of plant $(\mathrm{cm})$.

${ }^{\mathrm{x}}$ Least-squares mean values for plant area $\left(\mathrm{cm}^{2}\right)$, determined as the product of two perpendicular diameter measurements per plant.

${ }^{y}$ Least-squares mean values for diameter of stems $(\mathrm{cm})$ measured $1 \mathrm{~cm}$ above soil line on mature plants.

${ }^{\mathrm{z}}$ Least-squares mean values for number of capitula per plant. gial galls older than 3 weeks after maturation, i.e., color development, were not suitable for inoculations. All parts of YST leaves, i.e., petiole, midvein, and blade, were susceptible (Fig. 1B), and $15.2 \%( \pm 7.0 ; n=4)$ of the leaves were infected after one inoculation using this protocol. Immature resting spore galls appeared as small, white spheres at the time when sporangial galls developed color. Resting spore galls became dark upon maturation, about 20 days after inoculation (Fig. 1B, petiole).

Other protocols and refinements. Refinements in plant inoculation protocols resulted in greater proportion of infected leaves, adoption of a shorter incubation time for inoculation protocols, and development of a standard method for testing nontarget plant species. An experiment in which soil was removed from 4week-old plants (=exhumed) and bare roots placed in water (Fig. $2 \mathrm{~A}$ ) resulted in $40 \%$ of the leaves with galls (Tables 2 and 3 ) versus $25 \%$ galled leaves when the original protocol with potted plants was followed (Table 2). Venue (growth versus dew chamber) was not an important factor. The difference in rate of gall development between venues was approximately 1 day, and the significant interaction between "Medium" and "Incubator" for rank rating analysis resulted from the high value associated with the Water medium treatment for Growth Chamber (Table 2). The benefit of using exhumed plants was substantiated in another experiment that examined different incubation periods on the amount of disease; the proportion of infected leaves in that study was at least $45 \%$ (data not shown).

Incubation times shorter than 10 days resulted in successful infection of YST. Disease equivalent to amounts in other treatments resulted within 9 days of greenhouse incubation following 1 day of growth chamber incubation (data not shown). The model describing incubation time and symptom development is: $y=9.0+$ $0.6 x$, where $y$ is the number of days to the first macroscopic symptom, and $x$ is incubation time $\left(R^{2}=0.703\right)$. Models of time of incu-

Table 3. Least-squares means for effect of leaf binding materials on disease of yellow starthistle by Synchytrium solstitiale, compared with exhumed plant inoculations

\begin{tabular}{lccc}
\hline Treatment & $\begin{array}{c}\text { Sporangial } \\
\text { galls }^{\mathbf{w}, \mathbf{x}}\end{array}$ & $\begin{array}{c}\text { Diseased } \\
\text { leaves }^{\mathbf{y}}\end{array}$ & $\begin{array}{c}\text { Rank } \\
\text { rating }^{\mathbf{z}}\end{array}$ \\
\hline Control & $0 \mathrm{c}$ & $0 \mathrm{~d}$ & $1.0 \mathrm{~d}$ \\
Paper towel (PT) & $18 \mathrm{bc}$ & $7.4 \mathrm{~cd}$ & $12.4 \mathrm{c}$ \\
PT plus plastic wrap & $33 \mathrm{~b}$ & $10.3 \mathrm{c}$ & $20.0 \mathrm{~b}$ \\
Plastic wrap & $77 \mathrm{a}$ & $23.8 \mathrm{~b}$ & $32.3 \mathrm{a}$ \\
Exhumed plants & $90 \mathrm{a}$ & $39.4 \mathrm{a}$ & $32.5 \mathrm{a}$ \\
\hline
\end{tabular}

${ }^{\mathrm{w}}$ Total number of sporangial galls per plant.

${ }^{\mathrm{x}}$ Numbers followed by the same letter in each column are not significantly different $(P \leq 0.05)$.

y Least-squares mean values for average percent infected leaves per plant.

${ }^{\mathrm{z}}$ Least-squares mean values for analysis of rank values from disease ratings ( 0 to $10 ; 0=$ no disease).

Table 2. Effects of plant growth medium and incubation conditions on disease of yellow starthistle (YST) caused by Synchytrium solstitiale

\begin{tabular}{llcccc}
\hline \multicolumn{2}{c}{ Treatments } & & & & \\
\cline { 1 - 4 } Medium $^{\mathbf{u}}$ & Incubator $^{\mathbf{v}}$ & $\boldsymbol{n}$ & Gall development $^{\mathbf{w}, \mathbf{x}}$ & \% Leaves inf. $^{\mathbf{y}}$ & Rating rank $^{\mathbf{z}}$ \\
\hline Water & Growth chamber & 16 & $13.0 \mathrm{~b}$ & $40.0 \mathrm{a}$ & $43.8 \mathrm{a}$ \\
Water & Dew chamber & 16 & $13.8 \mathrm{ab}$ & $42.0 \mathrm{a}$ & $23.4 \mathrm{~b}$ \\
Soil & Growth chamber & 16 & $13.5 \mathrm{~b}$ & $24.0 \mathrm{~b}$ & $23.2 \mathrm{~b}$ \\
Soil & Dew chamber & 16 & $14.6 \mathrm{a}$ & $25.0 \mathrm{~b}$ & $21.4 \mathrm{~b}$ \\
Medium & & & 0.06 & $<0.01$ & 0.02 \\
Incubator & & & $<.01$ & 0.91 & 0.02 \\
M*I & & 0.71 & 0.95 & 0.05 \\
\hline
\end{tabular}

"Medium in which YST roots were grown. "Water" treatment had exhumed 4-week-old plants growing in flasks of water, and "Soil" treatment had 4-weekold plants growing in pots, i.e., not exhumed.

${ }^{v}$ Conditions for incubation were provided either in a growth chamber $\left(10 / 15^{\circ} \mathrm{C}\right.$ [night/day]) with an 8 -h photoperiod or a dew chamber $\left(\right.$ constant $13^{\circ} \mathrm{C}$ and constant light from a $40-\mathrm{W}$ incandescent light bulb).

${ }^{\mathrm{w}}$ Least-squares mean values for days following inoculation to development of orange sporangial galls.

${ }^{\mathrm{x}}$ Numbers followed by the same letter in each column are not significantly different $(P \leq 0.05)$.

${ }^{\mathrm{y}}$ Least-squares mean values for average percent infected leaves per plant.

${ }^{\mathrm{z}}$ Least-squares mean values for analysis of rank values from disease ratings ( 0 to $10 ; 0=$ no disease). 
bation versus amount of disease, as measured by proportion of infected leaves or disease severity rating, were not significant $(P=$ 0.92 and 0.06 , respectively). For example, least-squares means for amount of disease were 44.9 and $51.8 \%$ for proportion of infected leaves after $\leq 3$ days and 10 days incubation, respectively $(P=$ $0.16)$.

Tests of two different binding materials to wrap leaves around inoculum showed the amount of disease varied by the material used (Table 3). Both materials tested were useful as a means of maintaining free moisture during incubation on potted plants, but sporangial galls per plant and the proportion of infected leaves were significantly greater when leaves were bound with plastic wrap (Fig. 2B) than for the other binding treatments (Table 3). Although values for measures of disease effects were generally greatest in association with exhumed plants, data for sporangial gall counts and ranks of ratings were not significantly different from those bound only with plastic wrap (Table 3 ). The proportion of infected leaves was significantly greater with exhumed plants than for any of the other treatments, however. The wrapped-leaf protocol was selected for the general host range determination in this study.

Host range studies. Use of the leaf-wrap protocol resulted in significant infection of safflower, three Centaurea species (in addition to YST), and Cirsium neomexicana (Table 4). High levels of disease developed on YST. Disease developed also on three safflower cultivars ('S-345', 'CW 99OL', and 'Finch') and both Middle Eastern Carthamus species included in this study (Table 4). Centaurea cyanus, $C$. napifolia, $C$. sulphurea, and Cirsium neomexicana were infected to a lesser extent, compared to $C$. solstitialis (Table 4). There were 10 species that were not symptomatic.

Table 4. Host range determination for Synchytrium solstitiale using the leaf-wrap procedure

\begin{tabular}{|c|c|c|c|c|c|}
\hline Species 'cultivar' & $n^{\mathrm{t}}$ & Incidence $^{\mathrm{u}}$ & Leaves infected ${ }^{\mathrm{v}}$ & Gallsw $^{w}$ & Rating $^{x}$ \\
\hline \multicolumn{6}{|l|}{ Carthamus tinctorius } \\
\hline 'S-345'y & 4 & 50 & $5.2 \mathrm{bc}$ & $8.6 \mathrm{bc}$ & $29.2 \mathrm{bc}$ \\
\hline 'CW 990L'y & 5 & 60 & $5.4 \mathrm{bc}$ & $15.2 \mathrm{bc}$ & $39.0 \mathrm{abc}$ \\
\hline 'Finch'y & 4 & 100 & $10.3 \mathrm{abc}$ & $30.2 \mathrm{ab}$ & $56.8 \mathrm{a}$ \\
\hline C. glaucus & 6 & 17 & $2.1 \mathrm{c}$ & $15.8 \mathrm{bc}$ & $24.7 \mathrm{c}$ \\
\hline C. palaestinus & 8 & 50 & $10.7 \mathrm{abc}$ & $7.1 \mathrm{bc}$ & $34.7 \mathrm{bc}$ \\
\hline Centaurea calcitrappa & 6 & 0 & 0 & 0 & 0 \\
\hline C. cyanus & 6 & 83 & $5.4 \mathrm{bc}$ & $11.0 \mathrm{bc}$ & $39.8 \mathrm{abc}$ \\
\hline C. diffusa & 4 & 0 & 0 & 0 & 0 \\
\hline C. maculosa & 4 & 0 & 0 & 0 & 0 \\
\hline C. napifolia & 8 & 17 & $6.3 \mathrm{bc}$ & $3.8 \mathrm{bc}$ & $22.1 \mathrm{c}$ \\
\hline C. solstitialis ${ }^{\mathrm{Z}}$ & 25 & 88 & $18.2 \mathrm{a}$ & 43.8 a & 53.7 a \\
\hline C. sulphurea & 6 & 83 & $12.9 \mathrm{ab}$ & $23.7 \mathrm{abc}$ & $47.9 \mathrm{ab}$ \\
\hline Cirsium neomexicana & 8 & 50 & $6.3 \mathrm{bc}$ & $3.8 \mathrm{bc}$ & $26.7 \mathrm{c}$ \\
\hline C. quercitorum & 5 & 0 & 0 & 0 & 0 \\
\hline C. undulatum & 8 & 0 & 0 & 0 & 0 \\
\hline Cynara cardunculus & 3 & 0 & 0 & 0 & 0 \\
\hline C. scolymus & 4 & 0 & 0 & 0 & 0 \\
\hline Helianthus annuus 'Mammoth' & 12 & 0 & 0 & 0 & 0 \\
\hline Rhaponticum repens & 4 & 0 & 0 & 0 & 0 \\
\hline Saussurea nuda & 6 & 0 & 0 & 0 & 0 \\
\hline
\end{tabular}

t Total number of plants inoculated.

u Least-squares means, incidence (percent) of infection.

${ }^{v}$ Least-squares means, ratio (percent) of leaves infected. Numbers followed by the same letter in each column are not significantly different $(P \leq 0.05)$

${ }^{\mathrm{w}}$ Least-squares means for the number of galls per plant.

${ }^{\mathrm{x}}$ Least-squares means from analysis of ranked values of ratings ( 0 to $10 ; 0=$ no disease).

$y$ Inoculated at the 2-true-leaf stage.

z Target species.

Table 5. Effects of leaf-wrap inoculation by Synchytrium solstitiale on safflower (Carthamus tinctorius) and yellow starthistle (Centaurea solstitialis)

\begin{tabular}{|c|c|c|c|c|c|c|c|c|c|c|}
\hline \multirow[b]{2}{*}{ Species 'cultivar' } & \multirow[b]{2}{*}{ Treatment $^{w}$} & \multirow[b]{2}{*}{ Stage $^{x}$} & \multicolumn{2}{|c|}{ Height $^{\mathrm{q}, \mathrm{r}}$} & \multicolumn{2}{|c|}{ SDWT $^{r, s}$} & \multicolumn{2}{|c|}{ PropLvs $^{\mathrm{t}, \mathrm{u}}$} & \multicolumn{2}{|c|}{ Galls $^{u, v}$} \\
\hline & & & $\mathbf{1}^{\mathrm{y}}$ & 2 & 1 & 2 & 1 & 2 & 1 & 2 \\
\hline \multicolumn{11}{|l|}{ C. tinctorius } \\
\hline \multirow{2}{*}{ 'S-345' } & $\mathrm{C}$ & 2 & $9.2 \mathrm{a}$ & $17.7 \mathrm{a}$ & $0.16 \mathrm{a}$ & $0.44 \mathrm{a}$ & & & & \\
\hline & $\mathrm{I}$ & & $5.7 \mathrm{~b}$ & $10.3 \mathrm{~b}$ & $0.08 \mathrm{~b}$ & $0.14 \mathrm{~b}$ & $17.5 \mathrm{a}$ & 0 & $39.8 \mathrm{c}$ & 0 \\
\hline \multirow{2}{*}{ 'S-345' } & $\mathrm{C}$ & 4 & $24.7 \mathrm{a}$ & 12.5 & $0.45 \mathrm{a}$ & 0.36 & & & & \\
\hline & $\mathrm{I}$ & & $11.5 \mathrm{~b}$ & 9.7 & $0.22 \mathrm{~b}$ & 0.24 & $5.4 \mathrm{~b}$ & 0 & $21.0 \mathrm{bc}$ & 0 \\
\hline \multirow[t]{2}{*}{ 'CW 99-OL' } & $\mathrm{C}$ & 2 & $13.0 \mathrm{a}$ & $27.7 \mathrm{a}$ & $0.18 \mathrm{a}$ & 0.12 & & & & \\
\hline & I & & $5.8 \mathrm{~b}$ & $8.7 \mathrm{~b}$ & $0.08 \mathrm{~b}$ & 0.11 & $19.8 \mathrm{a}$ & 0 & $47.7 \mathrm{~b}$ & 0 \\
\hline \multirow[t]{2}{*}{ 'CW 99-OL' } & $\mathrm{C}$ & 4 & $23.2 \mathrm{a}$ & $30.5 \mathrm{a}$ & $0.38 \mathrm{a}$ & $0.55 \mathrm{a}$ & & & & \\
\hline & I & & $11.3 \mathrm{~b}$ & $26.5 \mathrm{~b}$ & $0.21 \mathrm{~b}$ & $0.24 \mathrm{~b}$ & $7.3 \mathrm{~b}$ & 0 & $11.0 \mathrm{c}$ & 0 \\
\hline \multirow[t]{2}{*}{ C. solstitialis } & $\mathrm{C}$ & $\mathrm{R}$ & $12.7 \mathrm{a}$ & 7.0 & $0.26 \mathrm{a}$ & $\mathrm{nd}^{\mathrm{z}}$ & & & & \\
\hline & I & & $7.8 \mathrm{~b}$ & 4.8 & $0.08 \mathrm{~b}$ & nd & $25.6 \mathrm{a}$ & 23.3 & $77.5 \mathrm{a}$ & 70.8 \\
\hline
\end{tabular}

q Least-squares means for plant height $(\mathrm{cm})$.

${ }^{\mathrm{r}}$ For each pair of control and inoculated treatments, numbers followed by the same letter are not significantly different $(P \leq 0.05)$.

s Least-squares means for aboveground, i.e., shoot plant dry weight (SDWT) (g).

${ }^{\mathrm{t}}$ PropLvs = Least-squares means for proportion (percentage) of symptomatic leaves per inoculated plant.

" Numbers in each column followed by the same letter are not significantly different $(P \leq 0.05)$.

${ }^{v}$ Least-squares mean for number of galls per inoculated plant.

${ }^{\mathrm{w}} \mathrm{C}=$ control, $\mathrm{I}=$ inoculated.

${ }^{x}$ Plant growth stage at inoculation; safflower (C. tinctorius), 2- or 4-leaf stage of growth; yellow starthistle (C. solstitialis), as rosettes (R).

${ }^{y}$ Replication.

${ }^{\mathrm{z}}$ nd $=$ no data 
Additional tests with safflower revealed that height and shoot dry weight, compared with respective controls, were significantly less after inoculation by $S$. solstitiale, and differences were equivalent to results with YST (Table 5, Fig. 3). Symptom development in safflower varied considerably between experiments, from clear evidence of macroscopic signs in the first replication started in August (as proportion of leaves, i.e., "PropLvs", and the number of galls, i.e., "Galls") to no visible symptoms in the second replication that was started in October (Table 5). Significant effects of disease on plant growth (height and shoot dry weight [SDWT]) were recorded on safflower, compared to controls, even in the absence of symptoms in the second replication (Table 5). Visible reduction in plant growth was also noted in these tests (Fig. 3). YST developed signs of disease after inoculation by $S$. solstitiale in all experiments, even when symptoms were absent on safflower (Table 5).

\section{Discussion}

Evidence from field and greenhouse experiments showed yellow starthistle is damaged by $S$. solstitiale (Tables 1 and 5). In another study (8), data from seedling inoculations suggest that a U.S. (California) accession of YST sustained greater damage from the disease than YST from France, particularly in terms of seedling survival. The fact that $S$. solstitiale infects YST rosettes during late winter and early spring makes it very desirable as a candidate for biological control in the United States. There is no biological pressure on very young YST in the field from the current complex of biological control agents in the United States, and environmental conditions for infection are likely favorable for disease by S. solstitiale where YST is a pest.

Several variations on the inoculation of YST rosettes were tested, and all resulted in successful infection. The original protocol with potted plants and plastic bags enabled maintenance of the fungus and supply of inoculum for the duration of this study. The discovery that disease resulted with an incubation time as short as 1 day led to adjusting the standard incubation period from 10 to 3 days. A greater amount of disease resulted from exhuming YST plants, because it was possible to submerge most of the rosette into the water during zoospore release. This likely provided optimal conditions and maximum exposure of leaves and petioles to zoospores as they swam to infection courts. Following incubation, the rosette was lifted so that only the roots remain submerged. Use of exhumed plants was involved and time-consuming, and although it was preferred for inoculum production, it was not uniformly applicable to inoculation of nontarget plants, most of which do not form rosettes. For this reason, the leaf-wrapping protocol was tested and selected for comparative inoculation of nontarget plant species. Use of this protocol resulted in levels of disease comparable to those recorded after inoculation of exhumed plants.

Results of the host range determination in this study and those reported by Widmer and Guermache (9) indicate YST is very susceptible to infection by $S$. solstitiale. Safflower and several other related species were also found susceptible in their study (9). Inoculation of three modern safflower cultivars and two other species of Carthamus from the Middle East in the present study substantiate the findings of Widmer and Guermache (9). Preliminary tests with safflower in this study resulted in disease also of the cultivars 'Centennial', 'Montola 2000', and 'Pacific 1' (data not shown), further substantiating the susceptibility of safflower to this pathogen. Data from this study suggest responses among safflower cultivars are similar to those recorded on YST, particularly in terms of incidence, proportion of leaves infected, and rating (Table 4). In one experiment, however, extreme differences in symptom development occurred on safflower between replications, ranging from clear macroscopic signs of disease to the absence of macroscopic symptoms (Table 5). Even without macroscopic signs of infection on safflower, measurable effects on plant growth, i.e., height and shoot dry weight, were recorded (Table 5, Fig. 3). Although there is no clear explanation for this variation in symptom development, the conclusion remains that inoculation of safflower by $S$. solstitiale following protocols used in this study resulted in measurable effects on plant growth.

Similar to findings of Widmer and Guermache (9), plants in the genus Centaurea and, in the present study Cirsium neomexicana, a native North American thistle, became infected by $S$. solstitiale. Widmer and Guermache (9) reported disease on two other native U.S. species in the genus Plectocephalus. On this basis, it can be concluded that $S$. solstitiale potentially has a broad host range under conditions favorable for disease and that both native and commercially important U.S. plant species may be affected. Such a conclusion raises particular concern about safety relating to use of S. solstitiale for biological control of YST in the United States. If additional evaluations of host range are performed for $S$. solstitiale, species representing other tribes of the Asteraceae, particularly those with important native species, would need to be included. It has been determined at this time that $S$. solstitiale may pose too great a risk for development as an agent for YST control and should not be proposed for use in the United States without additional study.

\section{Acknowledgments}

The authors thank Jami Michael both for technical assistance and for data processing during this study, and Craig Cavin for growing many of the test
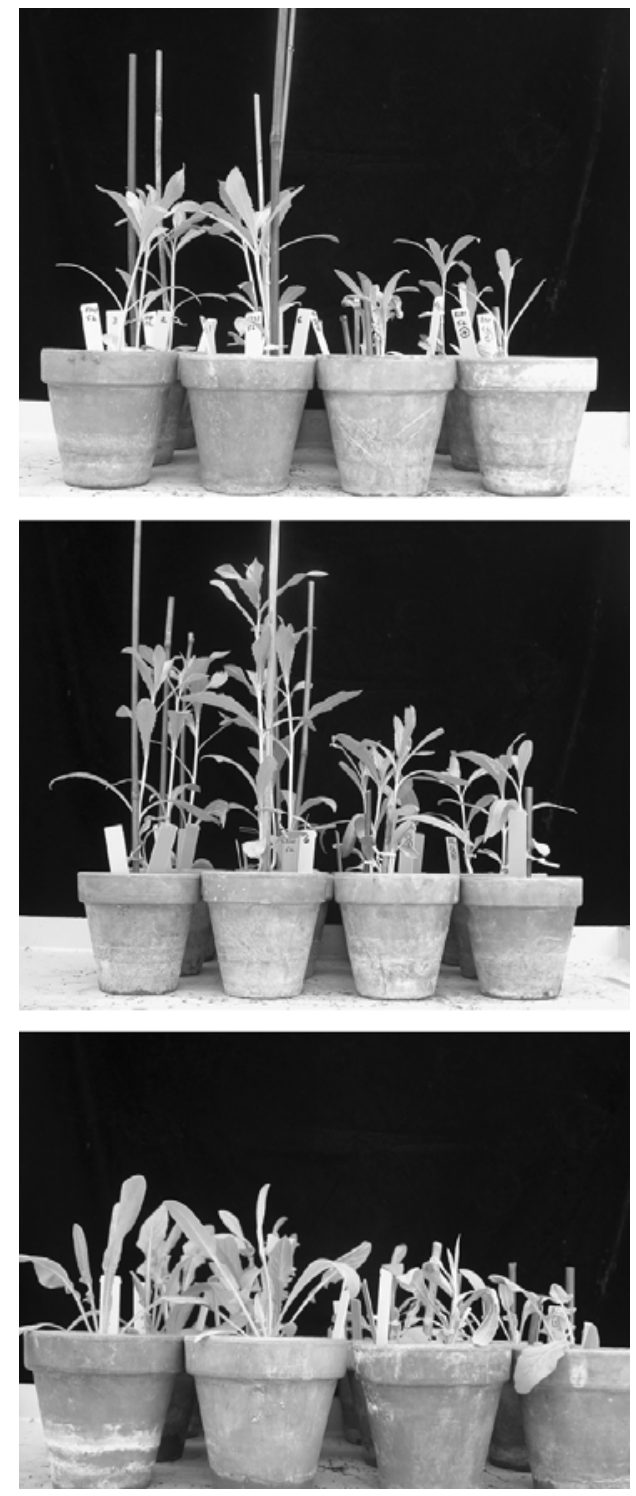

Fig. 3. Safflower and yellow starthistle after leaf-wrap inoculation by Synchytrium solstitiale. Safflower 'CW990L' was inoculated at the 2- or 4-leaf stage (top and middle, respectively), and yellow starthistle (bottom) was inoculated when 4 weeks old. Controls are the left two rows and the inoculated plants are the right two rows. 
plants. Seeds of test plants were provided from several sources and were greatly appreciated. Sources of seed included the Western Regional Plant Introduction Station, Pullman, WA, for exotic Carthamus species, two Cirsium species, and Saussurea nuda; Washington State University, Department of Entomology (Dale Whaley and Gary Piper) for Centaurea diffusa; Cindy Roché, Medford, OR, for Crupina vulgaris; Thouraya Souissi, Tunisia, for Centaurea napifolia; Rancho Ana Botanic Garden, Claremont, CA (Michael Wall) for Cirsium neomexicana; Colorado State University, Ft. Collins (George Beck) for Rhaponticum repens; and to safflower seed producers, who supplied cultivars of safflower, specifically 'CW 99 OL' (K. Thompson, Cal/West Seeds, Woodland, CA), 'S-345' (A. Weisker, Seedtec, Woodland, CA), 'CH353' (Cargill, Dixon, CA), 'Centennial', 'Montola 2000', and 'Finch' (J. Bergman, Montana State University, Eastern Ag Research Center, Sidney, MT), and 'Pacific-1' (J. Klisiewicz, USDA [Ret.]). Thanks also to reviewers for very good help, and to Dana Berner specifically for excellent suggestions and advice about statistical analysis.

\section{Literature Cited}

1. Berner, D. K., and Bruckart, W. L. 2005. A decision tree for evaluation of exotic plant pathogens for classical biological control of introduced invasive weeds. Biol. Contr. 34:222-232.

2. Eskandari, F. M., Bruckart, W. L., III, and Widmer, T. L. 2008. Protocol for maintenance of Synchytrium solstitiale, cause of false rust on yellow starthistle, under greenhouse conditions. (Abstr.) Phytopathology 98:S214.

3. Eskandari, F. M., Bruckart, W. L., III, and Widmer, T. L. 2010. Host range determination of Synchytrium solstitiale: Issues as a candidate for biological control of yellow starthistle. (Abstr.) Phytopathology 100:S207.

4. Fisher, A. J., Woods, D. M., Smith, L., and Bruckart, W. L., III. 2007. Developing an optimal release strategy for the rust fungus Puccinia jaceae var. solstitialis for biological control of Centaurea solstitialis (yellow starthistle). Biol. Contr. 42:161-171.

5. Melching, J. S., Bromfield, and K. R., Kingsolver, C. H. 1983. The plan pathogen containment facility at Frederick, Maryland. Plant Dis. 67:717-722.

6. Pitcairn, M. J., Schoenig, S., Yacoub, R., and Gendron, J. 2006. Yellow starthistle continues its spread in California. Calif. Agric. 60(2):83-89.

7. Widmer, T. L. 2004. Synchytrium solstitiale sp. nov. causing a false rust on Centaurea solstitialis in France. Mycologia 96:407-410.

8. Widmer, T. L. 2006. Impact of Synchytrium solstitiale on yellow starthistle seedlings and mature plants. (Abstr.) Phytopathology 96:S122-S123.

9. Widmer, T. L., and Guermache, F. 2006. Factors affecting infection of yellow starthistle (Centaurea solstitialis) by Synchytrium solstitiale, causal agent of false rust disease. Plant Dis. 90:425-428.

10. Woods, D. M., Bruckart, W. L., III, Pitcairn, M., Popescu, V., and O'Brien, J. 2009. Susceptibility of yellow starthistle to Puccinia jaceae var. solstitialis and greenhouse production of inoculum for classical biological control programs. Biol. Contr. 50:275-280.

11. Woods, D. M., Pitcairn, M. J., Joley, D. B., Popescu, V. 2002. Seasonal impact of yellow starthistle biological control agents. Pages 60-62 in: Biological Control Program Annual Summary, 2001. D. M. Woods, ed. California Department of Food and Agriculture, Plant Health and Pest Prevention Services, Sacramento, CA. 